\title{
The Impact Of The Financial Sector Reforms On Savings, Investments And Growth Of Gross Domestic Product (GDP) In Ghana
}

Gordon Newlove Asamoah, Kwame Nkrumah University of Science and Technology, Ghana

\begin{abstract}
As part of reforms initiated in the mid 1980s, Ghana's financial sector was subjected to a major and extensive restructuring under two financial sector adjustment programs (FINSAP 1 and 2) and the reform for Non- bank financial institutions credit. Having determined that restructuring of the financial system was indispensable to the success of the Economic Recovery Program (ERP) begun in 1983, the government, embarked upon a financial sector reform program (FINSAP) in 1988. Against this background therefore there has been a wave of financial sector reforms partly in response to international political pressures and strive for globalization. This study was to examine financial liberalization as it was carried out in Ghana and to make an assessment of the impact of this policy on savings, investment and the growth of income (GDP) in the Ghanaian economy. This study attempted to investigate the question: How does financial liberalization affect interest rate, savings, investment and GDP in Ghana? Regression Analysis and savings-investment models were used to evaluate how the financial sector impacts on economic growth.
\end{abstract}

\section{INTRODUCTION}

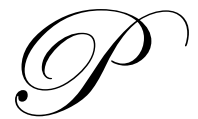

rior to 1983 Ghana operated a tightly regulated financial system. The impacts of these policies on economic development were found to be dismal. When the country turned to the International Monetary Fund (IMF) for assistance to reshape the macroeconomic structure, one of the policy packages was to reform the economy's financial system, which the Ghanaian policy makers obliged.

\section{THE RESEARCH QUESTION}

In the author's view very few studies have examined the impact of the financial sector reforms on the savings, investment and growth of GDP. This study attempted to investigate the following question:

How does financial liberalization affect interest rate, savings, investment and GDP in Ghana?

\section{Methodology And Data}

A simple macroeconomic model of savings and investment was used. The researcher also did empirical estimation with the use of regression Analyses to evaluate how the financial sector impacts on economic growth.

Data was obtained from The Central Bank of Ghana, World Bank CD-ROM, International Financial Statistical Year Books of the IMF and Central Bank of Ghana, Ghana Commercial Bank $9^{\text {th }}$ Annual Reports, (2002), Ghana Financial Market Department Report (First quarter, 2001) 
These were supplemented with data from the Ghana Statistical Services.

The data used for the Regression analyses was a monthly (that is monthly savings and monthly interest rates were used for the regression analyses) data.

The researcher also used yearly and seasonal dummy variables instead of post and pre-liberalisation as the dummies. This was because it was difficult to get enough and accurate data from the pre- liberalisation period.

\section{BACKGROUND OF THE GHANAIAN ECONOMY:}

Post-Independence Financial Sector Reforms: 1957- 2000

The post-independence financial sector reform can be classified into two major periods on the basis of the exchange rate regimes, the effective assignment of the exchange rates and structural changes. These include 1967 to 1982 known as the Pre-liberalization Period and 1983 to 2000 known as the Post-liberalization Period.

\section{Pre-Liberalization Period: 1957- 1982}

This was a period of fixed exchange rate regime with the view of maintaining low and stable inflation. This period saw devaluations of the local currency (the cedi) in 1967, 1971 and 1978. Growth rate of money on average was around 30\% in the period and rate of inflation hit over $100 \%$ by 1981 and overvaluation was around $69 \%$ by 1982. Growth and macro-economic stability was thus lost.

Before 1983 the formal banking system of the Ghanaian economy was dominated by the state owned banks. In fact they had a monopoly over the entire banking sector as regards their spread and operations. With the exception of two banks - Barclays and Standard Chartered, the country could not boast of any other foreign banks in the entire financial system. (A Country Economic Memorandum, The World Bank, 1995)

The several obstacles and restrictions served to undermine private sector confidence in the system as a whole. What is inferred from the foregoing is that the financial sector reforms were needed. Apart from the state of the financial sector outlined above, reforms were actually needed to encourage the development of the financial market: the deepening of financial intermediation, the creation of new instruments for the people to invest in and the establishment of new financial institutions which will all go to make the economy much more competitive in the world economy. The liberalization of the system therefore could not have come at a more opportune time.

\section{The Liberalization Period: 1983-2000}

This period saw drastic economic reforms in the history of Ghana. In particular, the official exchange rate was adjusted downwards in several steps from April 1983 through January 1986 culminating in the liberalization of the foreign exchange market at the end of the period.

This period can be categorized into two, in terms of foreign exchange objective. Whereas the objective of the period 1983-1991 was devoted to creating incentive for exporting and for maintaining Ghana's external competitiveness, that of 1992-2003 was unclear (Jebuni et.al, 1994). Consequently, inflation and growth rates for the two periods contrast sharply. Whereas per capita income growth rate averaged $1.8 \%$, despite the adverse development due to poor agricultural output in 1990, it decelerated to 1.0\% on average between 1992 and 2000. Inflation shows the same pattern between 1984 and 1991, the inflation rate was moderate hitting a low of 18\% in 1991. After a further decline in 1992, with increasing fiscal laxity and the tendency of the Central Bank to intervene unexpectedly in the foreign market to control depreciation of the exchange rate, inflation accelerated reaching a peak of an average of $59.5 \%$ in 1995 before declining to $30 \%$ in 1997.

IMF directed stabilization program was introduced in 1983, followed by Structural Adjustment program to restore fiscal and monetary discipline and realign prices by removing all controls. As part of Structure Adjustment 
Program, Financial Sector Adjustment Program (FINSAP) was launched in 1987 to address the deterioration in the financial sector. Years of mismanagement and government interference in the administration of credit rendered most banks technically insolvent

By 1991, money supply growth rate fell by $20 \%$ annually; GDP growth rate averaged $5 \%$ per annum and inflation fell to $10 \%$. In 1992 all direct controls by the state were abolished to pave way for banks to formulate their own credit policies and to set their own interest rates (ISSER, 2001).

There was a policy that encouraged free entry into the formal financial sector. Many financial as well as non-bank financial institutions were established. From a pre-liberalization number of about two foreign and five states- owned banks with virtually no non-bank financial institutions the sector widened. As at 1990 (seven years after the sector reform) the Ghanaian banking sector comprised of the central bank-the Bank of Ghana, 9 commercial banks, and 3 merchant banks. As of now there are 143 banks comprising 7 Commercial banks, 8 Universal banks, 9 Development banks, 2 Merchant banks and 121 rural banks.

One of the most useful innovations was the establishment of the unit rural banks. It numbered about 100 after the liberalization of the financial sector. The non bank financial institutions was made up of a stock exchange, 21 insurance companies, the Social Security and National Insurance trust, two discount houses, the Home Finance Company, a venture capital company, a unit trust and a leasing company (GHANA: Country Report, World Bank document, 1995).

As a result of the reforms, Gross capital formation as a percentage of GDP has also seen ups and downs trend over the years. In 1960, it was $24.38 \%$ of GDP. By 1982, it has fallen to $3.38 \%$ of GDP. However, from 1984, it started picking up and by 2000; it is rose 24\% almost as it was in 1960s (World Bank and Ghana Statistical Service, 1996).

\section{Financial Liberalization In Ghana: Some Shortcomings}

To a very large extent the fact remains that financial sector liberalization has made and continues to make useful contributions to economic growth and development in the Ghanaian economy (World Bank Report, March, 1998).

The other side of the picture therefore is the assertion that the policy has been counter-productive at times. I discuss some reasons below:

To begin with it is asserted that the policy has increased the potential for financial fragility in the economy. An economy exhibits financial fragility if it possesses a propagation mechanism that allows small common economic disturbances to have large-scale effects on the financial structure and thus on real activity.

Secondly it is posited that the dangers of liberalization stem from the fact that the institutions needed to support the efficient functioning of the financial markets are not exceptional (World Development Report, 1989, p15). Certain pertinent measures that have to do with effective prudential regulation, supervision of financial intermediaries and enforcement of contracts and regulations are not well developed.

The lack of the supervision also accounted for fraudulent behaviour on the part of some managers and customers, which subsequently led to the bankruptcy and closure of the Bank for Housing and Construction.

\section{LITERATURE REVIEW}

\section{Interest Rates And Savings}

According to Shaw (1973), McKinnon (1973), in a financially repressed economy, real deposit and lending rates are often negative, with adverse consequences for the development of financial system, and savings and 
investment generally. As a remedy, the standard approach suggests establishing positive and real rates of interest on deposits and loans by, among other measures, eliminating interest rate ceilings and direct credit allocations through appropriate macroeconomic and structural policies (IMF Staff papers, 1990)

One of the most contentious issues in financial policy is the effect of interest rate on savings. There can be little doubt that short term temporary savings and interest rates have little effects on private savings behaviour since that is governed largely by expectations and plans regarding current and future incomes and expenditures. They alter the level of savings primarily by affecting the levels of investments and income. However, when there is a rise in interest rate that is expected to be permanent, the propensity to save will rise, hence removing repression will have a strong positive effect on savings (Shaw, 1973, p.73).

There is however another view that the financial liberalization can lower household savings by allowing easier access to credit and relaxing the income constraints on consumption spending. In many developing countries, financial liberalization has given rise to a massive growth in consumer loans (such as credit for cars, credit cards and so on). This is one of the reasons why the household savings rate declined and debt/income ratio rose in the 1980s in the United States (Blundell-Wignall and Browne, 1991).

\section{HOW THE FINANCIAL SECTOR REFORM AFFECT ECONOMIC GROWTH.}

This section tries to use the simple AK model to analyse how financial sector development can affect economic growth.

To capture the effects of financial sector reform on economic growth. Consider the simplest endogenous growth model - 'AK' model, where aggregate output is a linear function of the aggregate capital stock.

$\mathrm{Y}_{t}=\mathrm{AK}_{t}$

For simplicity, assumed that the economy produces a single good that can be invested or consumed $(\mathrm{Y}=\mathrm{C}+\mathrm{I})$. If it is invested, it depreciates at the rate $\delta$ per period. Gross investment then is equal to

$\mathrm{It}=\mathrm{K}_{t+1}-(1-\delta) \mathrm{K}_{t}$

In a closed economy without government spending, capital market equilibrium requires that gross savings $\left(\mathrm{s}_{t}\right)$ equals gross investment $\left(\mathrm{I}_{t}\right)$ hence assuming that a proportion 1- $\phi$ of savings is lost due to financial intermediation (Pagano 1993)

$\phi \mathrm{S}_{t}=\mathrm{I}_{t}$

$\mathrm{gt}+1=\mathrm{Y}_{t+1} / \mathrm{Y}_{t-1}=\mathrm{K}_{t+1} / \mathrm{K}_{t-1}$

Using equation (2) and leaving out the time indices, the steady - state growth rate can be written as

$\mathrm{g}=\mathrm{A} \frac{I}{Y}-\delta=A \phi s-\delta$

Equation (5) reveals how financial sector reform can affect growth. It can raise the proportion of savings channelled to investment ( $\phi$ ); it may increase the social marginal productivity of capital (A) and it can influence the private saving rate (s). 


\section{Affecting The Savings Rate}

The financial sector reform can affect economic growth by altering the saving rates. In this case the sign of the relationship is not obvious, this is because financial sector development may also reduce savings, and thereby growth. As capital markets develop, household gain better diversification of rate of return risk, while consumer credit becomes more readily available. Financial development also narrows the wedge between the interest rate paid by firms and that received by households. Each of these factors affects saving behaviour but in each case the effect is ambiguous.

\section{SAVINGS AND INVESTMENT MODEL AND DATA ANALYSIS}

\section{The Relationship Among Financial Sector Liberalization, Savings, Investment And Gross Domestic Product (GDP)}

The model below illustrates the relationship among financial sector liberalization, savings, investment and economic growth. Whether the financial sector liberalization is successful in promoting investment and economic growth will depend on the interest rate elasticity of Ghana. The real rate of interest exerts a positive influence on the ratio of savings to the Gross National Product (GNP).

Consider the diagram below:

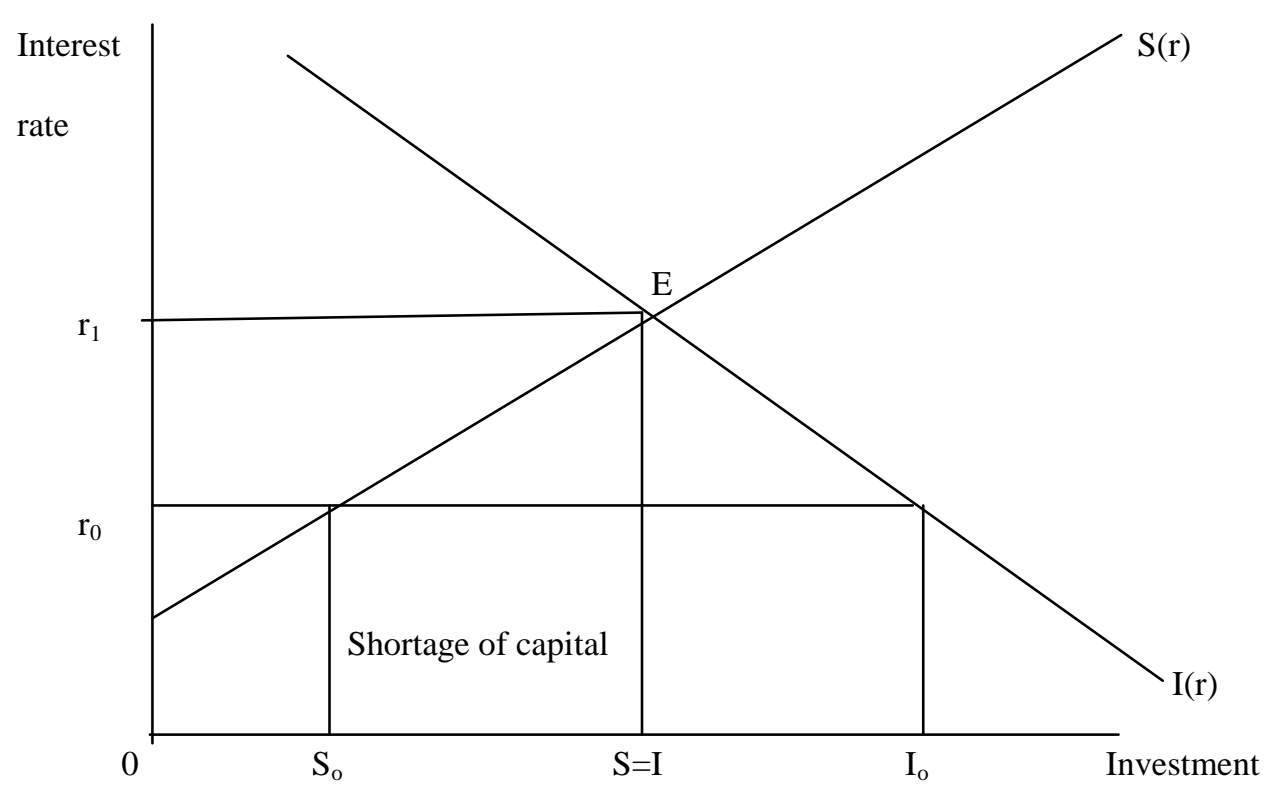

Fig. 1: Savings and Investment

The main function of the financial markets is to channel funds from savers to investors. Households and firms save their money in banks for future. These banks lend those funds to investors. However, savers consider the interest rate or what they will gain from saving their money at the bank before they make the decision to save. Lower interest rate discourages savers and hence reduces funds available for investors. On the other hand if there are many financial institutions competing for the savings, the interest rate will be high for savings, savers will save more, making more capital available for investors.

From Fig.1, assuming that savings is a function of interest rate only, the pre-liberalization interest rate is $r_{o}$ with investment being $I_{0}$. This means there is more demand for investment, but given the savings level $\left(\mathrm{S}_{0}\right)$, there is a gap between Savings and Investment in the economy. Demand for funds is $0 \mathrm{I}_{\mathrm{o}}$ but supply is only $0 \mathrm{~S}_{\mathrm{o}}$. Because the demand for fund is very high, interest rate for lending will be very exorbitant and investors who cannot afford to pay the high interest rate will fall out of the market and in so doing genuine investors rationed out of the credit market. 
This will go a long way to reduce the Gross Domestic product (GDP) and subsequently reduce standard of living and hence economic growth is retarded.

There will also be capital flight because foreigners will not like to bring their capital or save in the economy. The citizens of the country will also send their monies abroad where they can get good returns on their savings and investments.

Due to the repression in the economy, one of the measures the government will take is to liberalize the financial sector to attract more foreign capital. So after the liberalisation, the interest rate rises from $r_{o}$ to $r_{1}$. When the financial market (banking sector) is liberalized, more financial institutions crop up and competition sets in, giving rise to competitive interest rates, which are higher than the pre-liberalization interest rate. More people, both domestic and foreigners now bring in money to save since there is a good return for their money or savings. Investors therefore get more capital to undertake more investments. Because investors get more capital, they are able to produce more products and hence increase employment as well. This leads to an increase in the Gross Domestic product (GDP) of the economy. Once output or income is increased, more savings will be made. The multiplier effects of the investment have positive effects on the following macroeconomic variables. First of all, output will increase. More import substitutes will be produced domestically or some export goods can be produced for the international market. This will reduce the balance of payment deficit, which Ghana always experiences. Employment also increases, thereby alleviating the high rate of unemployment in the Ghanaian economy. Also increase in supply of goods and services will bring prices down and hence help to curtail inflation. Government also gets more revenue since investors as well as employees pay more taxes to the government. In summary, financial sector liberalization brings competition in the financial market, raises interest rate to encourage savings thereby making funds available for investment. Investments have favourable impact on all the macroeconomic variables and hence lead to economic growth.

\section{REGRESSION ANALYSIS} Ghana.

The regressions below throw more light on how the interest rate affects savings, investment and GDP in

\section{Regression Analysis (1)}

\section{Summary Output}

\section{Regression Statistics}

$\begin{array}{ll}\text { Multiple R } & 0.90341 \\ \text { R Square } & 0.81615 \\ \text { Adjusted R } & \\ \text { Square } & 0.801636 \\ \text { Standard Error } & 902.7618 \\ \text { Observations } & 42\end{array}$

\begin{tabular}{|c|c|c|c|c|c|}
\hline & Df & SS & MS & $\mathbf{F}$ & $\begin{array}{l}\text { Significance } \\
\text { F }\end{array}$ \\
\hline $\begin{array}{c}\text { Regression } \\
\text { Residual } \\
\text { Total }\end{array}$ & $\begin{array}{c}3 \\
38 \\
41\end{array}$ & $\begin{array}{l}1.37 \mathrm{E}+08 \\
30969197 \\
1.68 \mathrm{E}+08\end{array}$ & $\begin{array}{l}45826374 \\
814978.9\end{array}$ & 56.23014 & $4.82 \mathrm{E}-14$ \\
\hline & Coefficients & $\begin{array}{c}\text { Standard } \\
\text { Error }\end{array}$ & t Stat & P-value & Lower $95 \%$ \\
\hline $\begin{array}{c}\text { Intercept } \\
\text { R } \\
\text { D1 } \\
\text { D2 }\end{array}$ & $\begin{array}{c}8890.07 \\
42.22441 \\
-3876.81 \\
-2409.87\end{array}$ & $\begin{array}{l}673.0729 \\
30.04957 \\
416.4313 \\
370.2728\end{array}$ & $\begin{array}{l}13.20818 \\
1.405158 \\
-9.30961 \\
-6.50836\end{array}$ & $\begin{array}{c}8.86 \mathrm{E}-16 \\
0.168097 \\
2.4 \mathrm{E}-11 \\
1.15 \mathrm{E}-07\end{array}$ & $\begin{array}{l}7527.505 \\
-18.6078 \\
-4719.84 \\
-3159.45\end{array}$ \\
\hline
\end{tabular}


Regression above shows the relationship between Savings and interest rate using yearly dummy variables.

From the regression, there is a positive relationship between savings and interest rate in the Ghanaian economy from January, 2000 to June 2003. When interest rate increases over the years after the liberalization of the financial sector, there has been a corresponding increase in the savings. The slope has a positive high number of 42.2 , which shows a strong relationship. The $\mathrm{R}$ square is also high, that is 0.82 , which shows that the result is explained by the data used. However, the t-statistic is only 1.41 , which signifies that the result is not all that significant. Yearly dummy variables were imposed on the data to see if different years have different interest rate effect on savings. The effects were found to be negative with both the two dummy variables having a negative value of -3876.8 and -2409.87 respectively. That is the dummies were to explain the periods where interests are low and how they affect savings. So from the analysis it is realised that, the years with low interest rate resulted in lower deposits in the Ghanaian economy.

\section{Regression (2)}

\section{Summary Output}

\section{Regression Statistics}

\begin{tabular}{l|l} 
Multiple R & 0.80743 \\
R Square & 0.651943 \\
Adjusted R Square & 0.574596 \\
Standard Error & 442.9392 \\
Observations & 12
\end{tabular}

ANOVA
\begin{tabular}{|c|c|c|c|c|c|}
\hline & Df & SS & MS & F & Significance F \\
\hline Regression & 2 & 3307419 & 1653709 & 8.428901 & 0.008658 \\
Residual & 9 & 1765756 & 196195.1 & & \\
Total & 11 & 5073175 & & & \\
\hline
\end{tabular}

\begin{tabular}{|c|c|c|c|c|c|}
\hline & Coefficients & $\begin{array}{c}\text { Standard } \\
\text { Error }\end{array}$ & t Stat & P-value & Lower 95\% \\
\hline Intercept & 5898.251 & 791.8652 & 7.448554 & $3.9 \mathrm{E}-05$ & 4106.926 \\
i & 133.0499 & 32.77354 & 4.059673 & 0.002843 & 58.91091 \\
May-August & 450.7403 & 280.1338 & 1.609018 & 0.142073 & -182.967 \\
\hline
\end{tabular}

Also, from Regression (2) seasonal dummy variables were used with the interest rate to see the effects of the boom season on savings. I found out that there is a positive relationship between the variables. That is during the boom season, which in the case of Ghana is the cocoa season which starts from September to April, more people tend to save. Both the interest rate and the seasonal dummy have positive effects on savings as they have values of 133.1 and 450.7 respectively. The $\mathrm{R}$ square is 0.7 showing that the result is explained by the data. Though the $\mathrm{t}$ statistic for the dummy variable is only 1.6, which is not all that significant, the one for the interest rate has a high figure of 4.1 that means the result is very significant. This is significant result because in Ghana, during the cocoa season, more money is pumped into the economy. Most cocoa farmers get more money than they can consume immediately, therefore about $60 \%$ of the income of farmers find their way back to the banks in the form of savings. 


\section{Regression (3)}

\section{Summary Output}

\section{Regression Statistics}

$\begin{array}{ll}\text { Multiple R } & 0.978288 \\ \text { R Square } & 0.957047 \\ \text { Adjusted R Square } & 0.955329 \\ \text { Standard Error } & 7.67 \mathrm{E}+11 \\ \text { Observations } & 27\end{array}$

ANOVA

\begin{tabular}{|c|c|c|c|c|c|}
\hline & Df & SS & MS & F & Significance F \\
\hline Regression & 1 & $3.28 \mathrm{E}+26$ & $3.28 \mathrm{E}+26$ & 557.0328 & $1.32 \mathrm{E}-18$ \\
Residual & 25 & $1.47 \mathrm{E}+25$ & $5.89 \mathrm{E}+23$ & & \\
Total & 26 & $3.43 \mathrm{E}+26$ & & & \\
\hline
\end{tabular}

\begin{tabular}{|c|c|c|c|c|c|}
\hline & Coefficients & $\begin{array}{c}\text { Standard } \\
\text { Error }\end{array}$ & t Stat & P-value & Lower 95\% \\
\hline Intercept & $2.69 \mathrm{E}+11$ & $1.65 \mathrm{E}+11$ & 1.628773 & 0.115899 & $-7.1 \mathrm{E}+10$ \\
Private investment & 7.090084 & 0.300408 & 23.60154 & $1.32 \mathrm{E}-18$ & 6.471383 \\
\hline
\end{tabular}

Regression (3) analyses how private investment affect GDP of the Ghanaian economy. From the regression there is a very big positive relationship between private investment and GDP. The slope has a value of 7.1\%. This means that if private investment increases by $1 \%$, the GDP will increase by $7.1 \%$. In other words, the multiplier effect on GDP is $7.1 \%$. R square is 0.96 indicating that the result is well explained within the data. It also has significant t-stat of 23.6, which makes the result very important and significant. This is due to the fact that as investment increases, investors are able to buy more capital goods to increase production. Employment increases. These employees and investors get incomes, save to reinvest. The multiplier effect goes a long way to increase output and hence GDP of the Ghanaian economy.

\section{Regression (4)}

\section{Summary Output}

\section{Regression Statistics}

Multiple R $\quad 0.516973$

R Square $\quad 0.267261$

Adjusted R Square $\quad 0.237952$

Standard Error $\quad 4.37 \mathrm{E}+11$

Observations 27

ANOVA

\begin{tabular}{|c|c|c|c|c|c|}
\hline & Df & SS & MS & F & Significance F \\
\hline Regression & 1 & $1.74 \mathrm{E}+24$ & $1.74 \mathrm{E}+24$ & 9.118576 & 0.005759 \\
Residual & 25 & $4.78 \mathrm{E}+24$ & $1.91 \mathrm{E}+23$ & & \\
Total & 26 & $6.52 \mathrm{E}+24$ & & & \\
\hline
\end{tabular}

\begin{tabular}{|c|c|c|c|c|c|}
\hline & Coefficients & $\begin{array}{c}\text { Standard } \\
\text { Error }\end{array}$ & t Stat & P-value & Lower 95\% \\
\hline Private investment & $4.06 \mathrm{E}+11$ & $9.94 \mathrm{E}+10$ & 4.082143 & 0.000401 & $2.01 \mathrm{E}+11$ \\
Real interest rate & $8.22 \mathrm{E}+09$ & $2.72 \mathrm{E}+09$ & 3.019698 & 0.005759 & $2.62 \mathrm{E}+09$ \\
\hline
\end{tabular}

Regression (4) looks at the Private investment and interest rate. 
From the regression there is a positive relationship between private investment and real interest rate. Though the $\mathrm{R}$ square is small which means the result is not explained within the data, the $\mathrm{t}$-stats is very significant. This means that if real interest rate increases by 1 percent private investment will increase by $8.2 \%$. The right exchange rate is very crucial for the success of the financial sector. If the economy's exchange rate is strong against the other major currencies such as the US dollar and the British pound, people investing in the sector will not worry so much since they would not need to exchange so much of the Ghanaian cedis for the other currencies. Devaluation of the Ghanaian cedi is supposed to boost exports and reduce imports, but for devaluation to be successful, the demand for both Ghanaian imports and exports should be fairly elastic. But in the case of Ghana, both the imports and exports are inelastic so continuing devaluation policy will not help the economy but rather aggravates the problems of the financial sector

\section{Test Of The Impact Of The Economic Recovery Program (Model1)}

$$
\log (X)_{t}=K_{1}+K_{2} \log (E)_{t}+K_{3} D_{67-82}+K_{4} D_{67-71}+\varepsilon_{t} \ldots \ldots \ldots \ldots
$$

\section{Regression table 1}

\begin{tabular}{|c|c|c|}
\hline Independent Variable & Coefficient & P-value \\
\hline Intercept, K1 & -1.7584 & 0.0026 \\
\hline $\log (\mathrm{E})_{t}$ & 1.3893 & 0.00127 \\
\hline $\mathrm{D}_{67-82}$ & 2.1084 & $7.88 \mathrm{E}-11$ \\
\hline $\mathrm{D}_{67-71}$ & 0.5082 & 0.05084 \\
\hline R-square & \multicolumn{2}{|c|}{$92 \%$} \\
\hline $\begin{array}{c}\text { F-statistics at 5\% level of } \\
\text { Significance (3.27) DF }\end{array}$ & $100.02(2.98)^{* *}$ \\
\hline
\end{tabular}

From table 1 above the results of the regression of Exports (X) as share of GDP in real terms on nominal exchange rate, $\mathrm{E}$, and the variables $\mathrm{D}_{67-71}$ and $\mathrm{D}_{67-82}$ which are dummies for the economic recovery program which occurred in 1971 and 1983 respectively, show that the model as a whole has all the correct diagnostic statistics. Zero (0) represents the pre-recovery period and one (1) represents the post-recovery period. The diagnostic statistics show that there is no evidence not to reject the null hypothesis that the model as a whole does not explain variation in X. The high F-value at (5\%-alpham 3,26 degrees of freedom) implies that R-square is significantly different from zero and that about $92 \%$ of the variation in share of export in GDP is explained by the model. All the coefficients have a priori sign and each is significantly different from zero at 0.05 significant level. As expected, the rise in the nominal exchange rate, which occurred over the economic recovery and structure adjustment period, led to rise in exports. Thus nominal exchange rate depreciation coupled with outward-oriented trade liberalization policies of the structural adjustment program, other things being equal, according to the results, has positive impact on exports.

$$
\begin{aligned}
& \text { Fitted Equation } \\
& \log (\mathrm{X})_{t}=-1.7584+1.3893 \log (\mathrm{E})_{t}+2.1084 \mathrm{D}_{67-82}+\mathrm{D}_{67-71} \\
& \begin{array}{lllll}
0.0026 & 0.0013 & 7.88 \mathrm{E}-11 & 0.050 & \mathrm{p} \text {-value }
\end{array}
\end{aligned}
$$

Thus exchange rate elasticity of share of export in GDP in terms of depreciation is 1.3. A point rise in the nominal exchange backed by outward looking economic policy led to 1.3 point rise in exports. The significance of the positive relationship between the dummies and the exports implies that economic recovery program boosted exports. While export rose throughout the adjustment period, the trade balance has generally been falling and could be attributed to higher import growth rate. 


\section{SUMMARY OF FINDINGS, POLICY PRESCRIPTION, RECOMMENDATIONS AND CONCLUSION.}

\section{Summary Of Research And Findings}

This study has reviewed some major issues in interest rate reform and financial liberalization, with particular reference to Ghana. The relevance of recent theories to the operation of financial sector reforms was discussed. Modern financial analysis suggests that a reassessment of interest rate policies and financial reforms in the context of economic adjustment programs appears warranted.

The following findings were made:

1. The approach to interest rate policy and financial sector liberalization generally should take into account the initial state of the economy, especially the financial position of the private sector and the quality of prudential regulations over the financial system. If the macroeconomic environment is unstable and bank supervision is ineffective, interest rate liberalization should be gradual. This finding is consistent with those made by Villanueva and Mirakhor (1990. p. 529).

2. Financial intermediation can affect economic growth by acting on the saving rate, on the fraction of saving channeled to investment, or on the social marginal productivity of investment.

3. Impact of the Economic Recovery and Structural Adjustment Programs. High exchange rate is important for a sound financial system. The thrust of the economic recovery program, 1983-2000, was exchange rate devaluation, removal of trade barriers, sterilization of agricultural input subsidies, liberalization of the financial sector and interest rate decontrols and privatization of State Owned Enterprises. These financial and trade liberalization measures were intended to boost exports and increase income. The exchange rate devaluation and flexible exchange rate regime (1971/72 and 1983 onwards) had a positive impact on exports. Although growth rates of export were high, yet the trade balance deteriorated throughout the period of the adjustment. This reduced the effectiveness of financial sector reform program in Ghana.

\section{Policy Prescription}

1. Strong macroeconomic policies to stabilize the economy and reinvigorating the private sector should be pursued.

2. Strict supervision of the banking system must be strengthened, to minimize moral hazard in the banking system. The importance of strong banking regulatory and supervisory policies needs to be underscored, not only because they ensure the viability and health of the banking industry, which is their traditional microeconomic justification, but also because interest rate liberalization would be ineffectual without them.

3. Institutional changes should be in the forefront of financial sector reforms in Ghana. These should include a strong infrastructure that will provide for adequate information flow, credit appraisal and rating, and legal and accounting systems and development of equity financing. Firms' vulnerability to interest rate shocks would then be reduced, allowing more room for interest rate liberalization.

4. Furthermore, deposit insurance schemes should be instituted to safeguard depositors. This will encourage savers to put more money at the bank which could be channeled to investors to produce more to increase the gross domestic product of Ghana.

5. In terms of the specific interest rate strategy, two types of situations may be considered: where inflation is low and where it is high. A gradual program of interest rate liberalization that maintains positive real rates can proceed in the low inflation era. In a high inflation era, a strong and credible stabilization program and an equally strong set of prudential regulations are generally the best initial policy measures. Due to the high level of inflation in the Ghanaian economy the appropriate policies are to implement a strong and credible stabilization programs that will stimulate the private sector, and to strengthen the system of prudential controls over the banking sector. 


\section{CONCLUSION}

The aim of this study has been to look at the impact of the financial sector reforms on savings, investment and growth of gross domestic product of the Ghanaian economy.

Regression analysis and savings-investment models were used to analyze how the financial sector impacts on savings, investment and growth of GDP and consequently, how the financial sector reforms that were undertaken in Ghana affected savings, investment and growth of GDP. It is realized from the literature reviewed that, the percentage of credit allocated to the private firms and the ratio of credit allocated to private firms to GDP are strongly and robustly correlated with economic growth, the rate of physical capital accumulation and improvement in the efficiency of capital allocation. The research found out that financial services stimulate savings, investment and growth of GDP and for that matter economic growth by increasing the rate of capital accumulation and by improving the efficiency with which the economies use that capital. Schumpeter (1912) contends that wellfunctioning banks spur on technological innovation by identifying and funding those entrepreneurs with the best chances of successfully implementing innovative products and production process.

\section{REFERENCES}

1. A Country Economic Memorandum, the World Bank, (1995)

2. Bhattarai, K. (2000) Welfare and distributional impacts of financial liberalization in a developing economy: Lessons from a forward looking CGE Model of Nepal, department of economics, University of Hull, UK

3. Bhattarai, K.(2003) Role of financial markets in an economy, department of economics, University of Hull, UK

4. $\quad$ Ghana Commercial Bank $9^{\text {th }}$ Annual Reports, (2002)

5. Ghana Financial Market Department Report (First quarter, 2001)

6. Ghana: Country Report, World Bank Document, 1995

7. Greenwood, J. and Jovanovic, B (1990) Financial development, Growth and the distribution of income, journal of political economy 98 , October.

8. $\quad$ http://www.bog.gov.gh/publica/orla.htm

9. $\quad$ http://www.ecowas.int/wami-imao/english/press.htm

10. http://www.worldbank.org/html/extr/extme/jssp062998.htm

11. Institute of Statistical, Social and Economic Research (ISSER, 1995) "The State of the Ghanaian Economy "Wilco Publicity Services Ltd., Accra.,

12. Institute of Statistical, Social and Economic Research (ISSER, 2000 and 2001) " The State of the Ghanaian Economy "Wilco Publicity Services Ltd., Accra.

13. International Monetary Fund, (1998a), Towards a Framework for Financial Stability, Washington, DC.

14. International Monetary Fund, International Financial Statistics (November, 2001)

15. International Monetary Fund Staff paper, vol.37 no.3 September, 1990 (pp.509-536)

16. McKinnon, R.I., (1988), 'Financial Liberalization in Retrospect: Interest rate Polices in LDCs', in Gustav, Ranis and T. Paul Shultz (ed). The State of Development Economics: Progress and Prospectives, New York: Basil Blackwell, pp.386-410

17. Pagano, M., (1993) Financial markets and Growth: European Economics Review 37, Holland

18. Schumpeter, Joseph A., (1912) The Theory of Economic Development. Dunker and Humblot, translated by Redvers Opie. Cambridge, MA: Harvard University Press, 1934.

19. Shaw, E.S., (1973) Financial deepening in Economic Development (Oxford University Press, New York)

20. Villanueva, Delano and Mirakhor, Abbas (1990), Strategies for financial reforms: Interest rate policies, Stabilization, and Bank Supervision in Developing Countries, IMF Staff Papers, Vol.37, No.3,pp509-536

21. World Bank, (1999a), Global Economic Prospects, Washington DC: World Bank 


\section{NOTES}

